\title{
Physiological Quality of Soybean Seeds Treated with Carboxymethyl Cellulose and Fungicide
}

\author{
Fernando Ribeiro Teles de Camargo ${ }^{1}$, Isneider Luiz Silva ${ }^{1}$, Patricio Javier Robles Barros ${ }^{1}$, \\ Diego Palmiro Ramirez Ascheri ${ }^{1}$, Renato Souza Rodovalho ${ }^{2}$, Nilton Cezar Bellizzi ${ }^{3}$, \\ José Luis Ramírez Ascheri', Itamar Rosa Teixeira1, Ivano Alessandro Devilla1, \\ André José de Campos ${ }^{1}$
}

\author{
${ }^{1}$ State University of Goiás, Campus Exact and Technological Sciences-Henrique Santillo (CCET), Anápolis, Brazil \\ ${ }^{2}$ Institute Federal Goiano Campus Ceres, Ceres, Brazil \\ ${ }^{3}$ Department of Agronomy, State University of Goiás, Palmeirasde Goiás, Brazil \\ Email: ^Isneider.luiz@gmail.com
}

How to cite this paper: de Camargo, F.R.T., Silva, I.L., Barros, P.J.R., Ascheri, D.P.R., Rodovalho, R.S., Bellizzi, N.C., Ascheri, J.L.R., Teixeira, I.R., Devilla, I.A. and de Campos, A.J. (2017) Physiological Quality of Soybean Seeds Treated with Carboxymethyl Cellulose and Fungicide. American Journal of Plant Sciences, 8, 2748-2757. https://doi.org/10.4236/ajps.2017.811185

Received: August 29, 2017

Accepted: October 20, 2017

Published: October 23, 2017

Copyright $\odot 2017$ by authors and Scientific Research Publishing Inc. This work is licensed under the Creative Commons Attribution International License (CC BY 4.0).

http://creativecommons.org/licenses/by/4.0/

\begin{abstract}
Soybean is the most produced oil crop in the world, with great increase in its annual production as well as great generation of waste from its industrialization. The soybean hulls can be used for the elaboration of products such as carboxymethyl cellulose (CMC), adding high value to this residue and it can be used as a coating polymer in seeds. The objective of this work was to analyze the physiological quality of soybean seeds treated with CMC and fungicide, recording images to verify the effectiveness of the coating in the seeds. The experiment was randomized into factorial scheme $2 \times 4$ with four replicates, two soybean cultivars M-7110 and M-7739 and four types of coating: without (control), CMC, fungicide and fungicide/CMC. The variables analyzed were: vigor (first count), germination test, accelerated aging, length and dry mass of the radicle and hypocotyl length. The images were made with a scanning electron microscope (SEM) with zoom of 50 and 200 times. The CMC used alone or with fungicide, provided good physiological quality of soybean seeds. In some analyzes there was difference between the cultivars $\mathrm{M}$ 7110 and M 7739. The combination of CMC and fungicide provided a better coating on the seeds.
\end{abstract}

\section{Keywords}

Glycine max, CMC, Cultivars, Treatments, Microscope

\section{Introduction}

Soybean (Glycine $\max$ L.) is the most cultivated oil crop in the world [1]. Brazil 
is the second largest producer and the seeds have great economic importance for agribusiness. In the 2016/2017 harvest, Brazil had a production of 110.16 million tons of grains [1].

In order to achieve great productivity, several factors have to be considered, a good physiological quality of seeds is one of them, since the seed is the first agricultural input to be chosen, combined with appropriate mechanization and cultural treatments can achieve great productivity [2].

Soybean seed presents a continuous evolution with high investments in technology, always generating new cultivars and forms of treatment [3], e.g., Cultivar M-7110 (cycle early) and M-7739 (cycle late), in addition to being the most produced and commercialized cultivars in the Brazilian Midwest [4].

As a novel technique, seed coating, or film coating, consists of depositing a thin, uniform layer of a polymer on the surface of the seed. A very precise protective material with minimal impact on the environment can be used in conjunction with chemical and biological treatment [5].

The coating of seeds with films allows a uniform application of chemical and biological agents against the attack of pathogens, reducing in this way the impacts on the environment and health of the farmer. This method can also be used to control seed storage conditions, preventing the increase of humidity and guaranteeing its quality, since even a small increase in the moisture content of the seed is enough to reduce its germination capacity [6].

One of these polymers that act in the coating of seeds is the carboxymethyl cellulose that is obtained from chemical processes of the cellulose until obtaining the polymer granulated powder [7].

CMC is a natural polymer, derived from cellulose, marketed in solid form as the carboxymethylcellulose. It has the structure based on the $\beta$ - $(1 \rightarrow 4)$ -D-glucopyranose polymer of cellulose. Carboxymethylcellulose has been applications, such as: encapsulation processes and controlled release of active ingredients [5].

Another way, and the most widespread among producers for seed treatment and sanitary control, is the chemical treatment. Due to the benefits of seed treatment with fungicides in the control of pathogens and improvement in the initial development of seedlings, it is justified to investigate the effect of the application of agrochemicals associated or not, thus verifying their physiological potential [8].

However, in addition to increasing seed protection and assisting seedling initial development, seed dressing products and mixtures thereof should not adversely interfere with the physiological quality of the seed, either immediately after treatment or during the Storage [4].

Considering these facts and the fact that the treatment of seeds with polymers and chemical products still requires information, the objective in this work was to verify the physiological quality of early and late cycle soybean seeds submitted to the treatment with the polymer carboxymethyl cellulose, fungicide and evalu- 
ations with recording images to verify the effectiveness of the treatments in the coating of the seeds.

\section{Material and Methods}

Tests were developed in the Laboratory of Drying and Storage of Vegetable Products and chemistry laboratory from CCET-Henrique Santillo, Universidade Estadual de Goiás, Anápolis-GO, Brazil.

Seeds used in the experiment were produced in the 2016/2017 haverst. The seeds were supplied by a company assigned to Anápolis-GO, whose geographical coordinates are $16^{\circ} 22^{\prime} 22^{\prime \prime}$ south latitude and $48^{\circ} 53^{\prime} 08^{\prime \prime}$ west longitude and $1012 \mathrm{~m}$ altitude. The climate of the region according to the Köppen classification is Aw type, with dry winter and hot and rainy summers [9].

The produced cultivars were: M 7110 (early cycle) and M 7739 (late cycle), both cultivars belonging to category S2, coming from sieve (6.5) with $12 \%$ water content.

The soybean hull, were supplied by the company producing Brejeiro soybean oil (Anápolis, Goiás, Brazil), were oven dried with forced air recirculation (Marconi, MA-035) for $12 \mathrm{~h}$ at $105^{\circ} \mathrm{C}$. After drying, a soybean hull was ground in a vertical rotor Willy type mill with 4 movable knives and 4 fixed knives (SPlabor, SP-31), provided with a $1 \mathrm{~mm}$ opening mesh.

The cellulose pulp from the ground soybean hull was performed according to methodology proposed by Mussatto et al. (2006) [10], with some modifications. The crude pulp obtained was bleached according to the methodology proposed by Flauzino Neto et al. (2013) [11], with modifications. Carboxymethyl cellulose was obtained by acetylation of the cellulose from the soybean hull using the method described by Heinze et al. (2006) [12].

Seed treatment with CMC was done in proportions of $2 \%$ product concentration in water, 2 grams of the product to $100 \mathrm{~mL}$ of distilled water. The polymer was dissolved in $100 \mathrm{~mL}$ of water, with the aid of a stirrer, until the solution became homogeneous. After the seeds were placed into the solution with water and polymer for 5 minutes and subsequently, the seeds were taken to an oven at $35^{\circ} \mathrm{C}$ for one hour, so that the solution adhered completely in the seeds.

The experimental design was randomized in the factorial scheme $2 \times 4$, two soybean cultivars (M 7110 and M 7739) and four types of coating: no coating (control), 2\% carboxymethyl cellulose, Fungicide (Vitavax - Carboxine + Thiram-300 $\mathrm{mL}$ ) and $2 \%$ carboxymethyl cellulose + fungicide, with four replicates. The doses in $\mathrm{mL}$ were used according to the manufacturer's recommendation for $100 \mathrm{~kg}$ of seeds.

The efficacy and performance of the cellulose extraction of the soybean hulls was determined by means of the Kappa number [13] of the cellulose pulps, which informs the content of non-extracted residual lignin present in the cellulosic pulp [14].

The CMC was characterized by the degree of substitution (DS) which was 
determined following the procedure of ASTM 1439-03 [15].

The first count test for germinations was conducted with TPG, with the aim to evaluate vigor, considering the percentage of normal plants present in the fifth day after the beginning of tests [16].

The Standard Germination Test (TPG), viability was evaluated, with four 50 -seed replications placed in an acrylic box (gerbox), containing a substratum. The germitest paper, previously moisturized with distilled water, is equivalent to paper weight threefold. The gerboxes were stored in a germinator at $25^{\circ} \mathrm{C}$. An evaluation was carried out on the eight day after test performance. The percentage of normal plants was taken into account [16].

The plant length test was performed on four replicates of 10 seeds of each treatment distributed on germitest paper rolls moistened with deionized water in the proportion of 2.5 per $1(\mathrm{ml}$ of distilled water per mass of the dry paper in grams) and kept in a germinator at $25^{\circ} \mathrm{C}$ for seven days [17]. On the moistened paper towel was drawn a line in the upper third, in the longitudinal direction, in which the seeds were placed so as to direct the micropyle downwards. The length of the primary root and seedlings considered normal [16] was determined at the end of the seventh day, using a millimeter ruler

The dry mass of seedlings was determined using the normal seedlings from the shoot length and root length test. Each replicate was packed in paper bags and forced into the oven with forced air circulation maintained at $80^{\circ} \mathrm{C}$ for 24 hours [17]. After this period the bags were removed and placed in a desiccator and afterwards each repetition was weighed in a digital scale with an accuracy of $0.001 \mathrm{~g}$. The results were expressed as $\mathrm{mg}$ seedlings $\mathrm{s}^{-1}$.

The accelerated aging test was performed using a single layer of seeds placed on a metal screen attached to the gerbox plastic box containing $40 \mathrm{~mL}$ of water in the bottom. The boxes were capped in order to obtain 100\% RH inside and were kept in a BOD incubator at $42^{\circ} \mathrm{C}$ for 48 hours. After each period, four samples of 50 seeds were placed to germinate, following the method described for the germination test. The results were expressed in percentage [16].

Scanning Electron Microscopy (SEM) performed in an electronic scanning electron microscope (Hitachi - TM3030 plus) with zoom 50x and 200x.

The variables evaluated were submitted to analysis of variance, $\mathrm{F}$ test and when significant the means were compared by Scott Knott test at the $\mathrm{p}<0.05$ probability level. Sisvar 5.6 program was used for statistical analysis [18].

\section{Results and Discussion}

The cellulose pulps of the soybean hull presented low Kappa numbers, being these, respectively, $7.07 \pm 0.29$ and $0.32 \pm 0.03$, obtained with a $1 \%$ (w/w) sodium hydroxide aqueous solution in a solid:liquid ratio of $1: 20$ (w:v) for $2 \mathrm{~h}$ at $90^{\circ} \mathrm{C}$ under. After the alkali treatment, the fibers were treated with a solution made up of equal parts (v:v) of acetate buffer and aqueous sodium chlorite ( $2 \mathrm{wt} \% \mathrm{NaC}$ $1 \mathrm{O}_{2}$ in water) in a solid:liquid ratio of $1: 75$ (w:v) for $4 \mathrm{~h}$ at $95^{\circ} \mathrm{C}$. 
The Kappa number by the bleached pulp indicates that the pulping and bleaching process of the soybean hull was successful, yielding a good raw material for the synthesis of carboxymethyl cellulose with a degree of substitution of 1.56 under the carboxymethylation conditions using a ratio of $2.1 \mathrm{~g}$ of chloroacetic acid per gram of bleached cellulose pulp for $192 \mathrm{~min}$ of reaction under a constant temperature of $63^{\circ} \mathrm{C}$.

The degree of substitution (DS) of the CMC synthesized from the soybean hull is higher than the DS of the commercial CMC that reaches a value of 0.7 [19].

The vigor test showed a significant difference for the interaction between cultivars and seed coat type. The seeds with fungicide presented seeds with low vigor when compared to the other treatments applied to cultivar M 7110 (Table 1). In cultivar M 7739, it was observed higher vigor when treated with the combination of CMC + fungicide. The control, in this case, presented the lowest value of vigor among the treatments studied.

Among the cultivars the vigor was differentiated only in the control and fungicide. The seeds M 7110 without cover showed higher, while M 7739 was higher when its seeds were treated with fungicide.

In the germination test, there were no statistically significant differences between treatments. However, it can be seen from Table 1 that a larger number of germinated seeds were observed in the control and CMC of the M 7110, whereas for M 7739 germination was observed when the seeds were treated with CMC + fungicide.

Accelerated aging is another test that indicates seed vigor [20]. Among the coating types, the seeds M 7110 is the one with the greatest vigor variation, and its worst result for the treatment with $\mathrm{CMC}+$ fungicide mixture and its better performance with CMC. The best treatments for seeds M 7739 were the compound coating with fungicides and CMC + fungicide.

In the fungicide treatment on the seeds M 7110 and the control for seeds $M$

Table 1. Summary values of the first count, germination and accelerated aging for soybean seeds (M 7110 and M 7739) submitted to different types of chemical coating (fungicide, $\mathrm{f}$ ) and polymer (carboxymethylcellulose, CMC).

\begin{tabular}{cccccc}
\hline & & \multicolumn{3}{c}{ Seed coatings } \\
& Cultivar & Control & CMC & Fungicide & CMC + F \\
\cline { 2 - 5 } First count (vigor) (\%) & M 7110 & $82.00 \mathrm{~A} \mathrm{a}$ & $84.00 \mathrm{~A} \mathrm{a}$ & $23.00 \mathrm{~B} \mathrm{~b}$ & $85.50 \mathrm{~A} \mathrm{a}$ \\
& M 7739 & $63.50 \mathrm{~B} \mathrm{~b}$ & $82.50 \mathrm{~A} \mathrm{a}$ & $80.50 \mathrm{~A} \mathrm{a}$ & $89.0 .0 \mathrm{~A} \mathrm{a}$ \\
Germination (\%) & M 7110 & $90.00 \mathrm{~A} \mathrm{a}$ & $87.50 \mathrm{~A} \mathrm{a}$ & $87.50 \mathrm{~A} \mathrm{a}$ & $88.00 \mathrm{~A} \mathrm{a}$ \\
& M 7739 & $84.00 \mathrm{~A} \mathrm{a}$ & $85.00 \mathrm{~A} \mathrm{a}$ & $87.50 \mathrm{~A} \mathrm{a}$ & $91.00 \mathrm{~A} \mathrm{a}$ \\
Speedy aging (\%) & M0 7011 & $65.00 \mathrm{~A} \mathrm{~b}$ & $82.50 \mathrm{~A} \mathrm{a}$ & $36.50 \mathrm{~B} \mathrm{c}$ & $9.50 \mathrm{~B} \mathrm{~d}$ \\
& M 7739 & $43.50 \mathrm{~B} \mathrm{~b}$ & $54.50 \mathrm{~B} \mathrm{~b}$ & $77.50 \mathrm{~A} \mathrm{a}$ & $73.00 \mathrm{~A} \mathrm{a}$ \\
\hline
\end{tabular}

${ }^{\star}$ Averages followed by the same uppercase and lowercase letters in the row and column, respectively, do not differ statistically by the Scott Knott test ( $<<$ $0.05)$. 
7739 , the percentage of vigor of the seeds of the other treatments can be considered ideal for a lot of seeds, since they present values superior to $80 \%$, indicating good quality of the Seed lot [21].

Ludwig et al. [8] working with combinations of some chemicals, the authors found values similar to this one, where the percentages of vigor of the soybean seeds were lower than $85 \%$, and with a proviso only for the treatment that was composed by fungicide, which provided an even greater reduction in the percent vigor of soybean seeds.

Seagalin et al. [22] studying the effects of different volumes of chemical syrup on soybean seeds found data that corroborate this study.

The treatments with $\mathrm{CMC}$ and $\mathrm{CMC}+$ fungicide coatings, did not drastically affect the percentage of germination of both cultivars where the values were always higher than $84 \%$ of germination. These results highlight the efficiency of the chemical treatment used here, because in order to be considered effective, it must not present a phytotoxic effect on the physiological quality of the seeds.

Dan et al. [23], Coradi et al. [24] and Cunha et al. [20], also found values above $84 \%$ in their work with chemical treatment in soybean seeds.

Accelerated aging was the test that presented the highest percentage variation of normal seedlings (Table 1). This test is used to verify if the seed can germinate and generate a normal seedling after being subjected to great stress [21]. According to Menten and Moraes [25] chemical and polymer treatments have little effect on the performance of soybean seeds, however, it is expected that seeds even after stress present values greater than $60 \%$ of normal plants. Cunha et al. [20] found much higher values for accelerated aging, where in their work the percentage was always greater than $85 \%$ of normal seedlings.

Applying the CMC as a coating film of soybean seeds M 7110 provided a larger number of vigorous seeds, which can be seen in the tests of vigor (84\%) and accelerated aging $(82.5 \%)$ (Table 1 ). The highest vigor when using the CMC can be justified because it acts as a regulator of entry and exit of substance of the seeds [7].

Based on the results of the comparison test of averages for radicle and hypocotyl and total length and dry masses of radicle and hypocotyl (Table 2), it was observed that although these variables showed differences between the treatments for the two cultivars used, Based on these determinations it is not possible to infer if there was a positive or negative effect of the use of chemical products on the physiological quality of the seeds, since the information obtained in the vigor tests of seed lots should be interpreted taking into consideration, besides length of plants, also the percentage of germination [26].

When analyzing the radicle length, it is possible to observe that the seeds $M$ 7739 was the one that showed the largest in all the types of cover used, thus showing that the cultivar presents larger plants. Fungicide coating impaired radicular size in seeds M 7110. Hypocotyl length had no difference between the cultivars, but with a proviso for the fungicide overlay in seeds M 7110, which 
Table 2. Summary values of the length and dry mass of the radicle and hypocotyl for soybean seeds (M 7110 and M 7739) submitted to different types of chemical coating (fungicide, f) and polymer (carboxymethyl cellulose, CMC).

\begin{tabular}{|c|c|c|c|c|c|}
\hline & \multirow{2}{*}{ Cultivar } & \multicolumn{4}{|c|}{ Seed coatings } \\
\hline & & Control & $\mathrm{CMC}$ & Fungicide & $\mathrm{CMC}+\mathrm{F}$ \\
\hline Radicle & M 7110 & $6.82 \mathrm{~B} \mathrm{a}$ & $6.51 \mathrm{~B} \mathrm{a}$ & $4.12 \mathrm{~B} \mathrm{~b}$ & $7.71 \mathrm{~B} \mathrm{a}$ \\
\hline lenght $(\mathrm{cm})$ & M 7739 & $13.60 \mathrm{~A} \mathrm{a}$ & $14.08 \mathrm{~A} \mathrm{a}$ & $12.80 \mathrm{~A} \mathrm{a}$ & $15.18 \mathrm{~A} \mathrm{a}$ \\
\hline \multirow{2}{*}{ Hypocotyl length (cm) } & M 7110 & $7.85 \mathrm{~A} \mathrm{a}$ & $8.50 \mathrm{~A} \mathrm{a}$ & $4.32 \mathrm{~B} \mathrm{~b}$ & $8.01 \mathrm{~B} \mathrm{a}$ \\
\hline & M 7739 & $7.51 \mathrm{~A} \mathrm{~b}$ & $7.22 \mathrm{~A} \mathrm{~b}$ & $9.74 \mathrm{~A} \mathrm{a}$ & $9.75 \mathrm{~A} \mathrm{a}$ \\
\hline \multirow{2}{*}{ Radicle dry mass (mg) } & M 7110 & $7.15 \mathrm{~A} \mathrm{a}$ & $6.24 \mathrm{~A} \mathrm{a}$ & $3.50 \mathrm{~A} \mathrm{~b}$ & $7.19 \mathrm{~A} \mathrm{a}$ \\
\hline & M 7739 & $3.25 \mathrm{~B} \mathrm{~b}$ & $5.75 \mathrm{~A} \mathrm{a}$ & $3.00 \mathrm{~A} \mathrm{~b}$ & $3.00 \mathrm{~B} \mathrm{~b}$ \\
\hline \multirow{2}{*}{ Hypocotyl dry mass (mg) } & M 7110 & $18.68 \mathrm{~A} \mathrm{a}$ & $19.84 \mathrm{~A} \mathrm{a}$ & $13.44 \mathrm{~B} \mathrm{~b}$ & $20.89 \mathrm{~A} \mathrm{a}$ \\
\hline & M 7739 & $19.50 \mathrm{~A} \mathrm{a}$ & $23.50 \mathrm{~A} \mathrm{a}$ & $20.50 \mathrm{~A} \mathrm{a}$ & $18.00 \mathrm{~A} \mathrm{~b}$ \\
\hline
\end{tabular}

*Averages followed by the same uppercase and lowercase letters in the row and column, respectively, do not differ statistically by the Scott Knott test ( $\mathrm{p}<$ $0.05)$. 


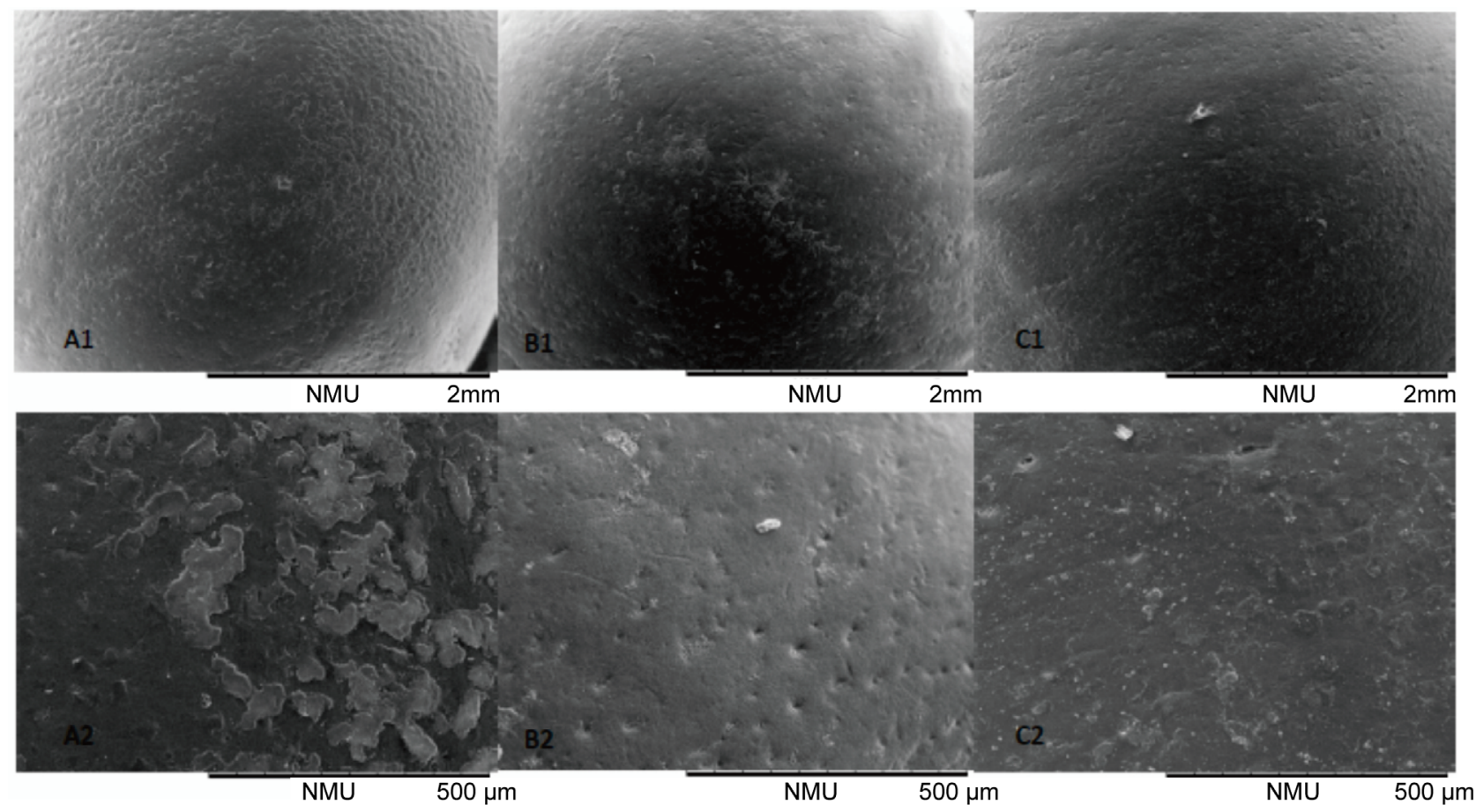

Figure 1. Microscopic images of the coating on soybean seeds. A1 and A2: Witness, 50× and 200×, respectively; B1 and B2: CMC, $50 \times$ and 200×, respectively; $\mathrm{C} 1$ and C2: CMC + Fungicide, 50× and 200×, respectively.

Dan et al. [23] and Ludwig et al. [8], when using coating polymers in soybean seeds associated with other products such as micronutrients and some chemicals, also verified that the use of products is efficient for the coating on soybean seeds, besides that these treatments can cause an addition in the quality of soybeans.

\section{Conclusion}

According to the conditions of the present work, it was concluded that the coatings influenced vigor, accelerated aging, radicle and hypocotyl length and dry mass of radicle and hypocotyl of the soybean seeds M 7110 and M7739, without influencing the germination of the seeds. The soybean seeds M 7110 were more sensitive to the toxicity of chemical treatments. The soybean seeds M 7739 presented higher root lengths. Coating of soybean seeds with CMC combined with fungicide, or without combination, provides a good coating of seeds.

\section{Acknowledgements}

To the Foundation for Support of Higher Education (CAPES) the partial funding of research and by the scholarship of the first, second and third authors.

\section{References}

[1] Conab-Companhia Nacional de Abastecimento. Grãos: sétimo levantamento da safra 2016/2017. [Conab-National Supply Company. Grains: Seventh Survey of 2016/2017 crop,] April/2017. 
http://www.conab.gov.br/OlalaCMS/uploads/arquivos/17_04_17_17_20_55_boleti m_graos_abr_2017.pdf

[2] França Neto, J.B., Krzyzanowski, F.C. and Henning, A.A. (2010) The Importance of Using High Quality Soybeans. Informativo Abrates, 20, 37-38.

[3] Piccinin, G.G., Braccini, A.L., Dan, L.G.M. and Lima, L.H.S. (2013) Influence of Storage on the Physiological Quality of Soybean Seeds Treated with Insecticides. Ambiência Guarapuava, 9, 289-298. https://doi.org/10.5777/ambiencia.2013.02.04

[4] Trafane, L.G. (2014) Industrial Treatment of Soybean Seeds and Their Reflections on the Quality during the Period of Storage. Dissertação (Ciências e Tecnologia de Sementes), Universidade Federal de Pelotas, Pelotas, 38.

[5] Oliveira, A.F.de., Soldi, V., Coelho, C.M.M., Miqueloto, A. and Coimbra, J.L.M. (2009) Preparation, Characterization and Properties of Polymer Films with Potential Application in the Coating of Seeds. Química Nova, 32, 1845-1849.

[6] Falguera, V., Quintero, J.P., Jimenez, A., Muñoz, J.A. and Ibarza, A. (2011) Edible Films and Coatings: Structures, Active Functions and Trends in Their Use. Trends in Food Science \& Technology, 22, 292-303. https://doi.org/10.1016/j.tifs.2011.02.004

[7] Bertoldo, J.G., Coimbra, J.L.M., Barili, L.D., do Vale, N.M., Coan, M.M.D., de Oliveira, A.F. and Soldi, V. (2010) Use of Polymers in the Technological Quality of Bean Grains under Storage Conditions. Semina: Ciências Agrárias, 31, 975-984. https://doi.org/10.5433/1679-0359.2010v31n4p975

[8] Ludwig, M.P., Oliveira, S., Avelar, S.A.G., Rosa, M.P., Filho, O.A.L. and Crizel, R.L. (2015) Storage of Treated Soybeans and Their Effect on Seedling Performance. Tecnologia e Ciência agropecuária, 9, 51-56.

[9] Pereira, A.R., Angelocci, L.R. and Sentelhas, P.C. (2002) Agrometeorology: Fundamentals and Practical Applications. Agropecuária, Guaíba, 478 p.

[10] Mussatto, S.I., Dragone, G., Rocha, G.J.M. and Roberto, I.C. (2006) Optimum Operating Conditions for Brewer's Spent Grain Soda Pulping. Carbohydrate Polymers, 64, 22-28. https://doi.org/10.1016/j.carbpol.2005.10.033

[11] Flauzino Neto, W.P., Silvério, H.A., Dantas, N.O. and Pasquini, D. (2013) Extraction and Characterization of Cellulose Nanocrystals from Agroindustrial ResidueSoy Hulls. Industrial Crops and Products, 42, 480-488. https://doi.org/10.1016/j.indcrop.2012.06.041

[12] Heinze, T. and Liebert, T. (2001) Unconventional Methods in Celulose Functionalization. Progress in Polymer Science, 26, 1689-1762. https://doi.org/10.1016/S0079-6700(01)00022-3

[13] Technical Association of the Pulp and Paper Industry (TAPPI) (2006) Standard Methods T 236 om-06. Tappi Test Methods, Atlanta.

[14] Segura, T., Dos Santos, J., Sarto, C. and Da Silva Jr., F. (2016) Effect of Kappa Number Variation on Modified Pulping of Eucalyptus. BioResources, 11, 98429855. https://doi.org/10.15376/biores.11.4.9842-9855

[15] ASTM-American Society for Testing and Materials (2003) Standard Test Methods for Sodium Carboxymethylcellulose (ASTM:D1439-03). STM International West Conshohocken.

[16] Brasil (2009) Ministry of Agriculture, Livestock and Supply. Rules for Seed Analysis/Ministério da Agricultura, Pecuária e Abastecimento. Secretaria de Defesa Agropecuária, Brasília: Mapa/ACS, 399. 
[17] Nakagawa, J. (1999) Performance Tests Based on Seedling Performance. In: Krzyzanowski, F.C., Vieira, R.D. and França Neto, J.B., Eds., Vigor de sementes: Conceitos e testes, ABRATES, Londrina, 1-24.

[18] Ferreira, D.F. (2014) Sisvar: A Computer Statistical Analysis System. Ciência e Agrotecnologia, 35, 1039-1042.

[19] Nóbrega, K. and Amorim, L. (2015) Influence of the Molar Mass of CMC in the Rheological Behavior and of Filtration of Clay Suspensions. Cerâmica, 61, 399-408. https://doi.org/10.1590/0366-69132015613601904

[20] Cunha, R.P., Correa, M.F., Schuch, L.O.B., Oliveira, R.C., Abreu Jr., J.S., Silva, J.D.G. and Almeida, T.L. (2015) Different Treatments of Seeds on the Development of Soybean Plants. Ciência Rural, 45, 1761-1767. https://doi.org/10.1590/0103-8478cr20140742

[21] Carvalho, N.M. and Nakagawa, J. (2012) Seeds: Science, Technology and Production. Funep, Jaboticabal, 590.

[22] Segalin, S.R., Barbieri, A.P.P., Huth, C., Beche, M., Mattioni, N.M. and Mertz, L.M. (2013) Physiological Quality of Soybean Seeds Treated with Different Spray Volumes. Journal of Seed Science, 35, 501-509. https://doi.org/10.1590/S2317-15372013000400012

[23] Dan, L.G.M., Dan, H., Barroso, A.L.L. and Braccini, A.L. (2010) Physiological Quality of Soybean Seeds Treated with Insecticides under Storage. Revista Brasileira de Sementes, 32, 131-139. https://doi.org/10.1590/S0101-31222010000200016

[24] Coradi, P.C., Milane, L.V., Camilo, L.J., Prado, R.L.F. and Fernandes, T.C. (2015) Quality of Soybeans Stored at Low Temperatures. Brazilian Journal of Biosystems Engineering, 9, 197-208.

[25] Menten, J.O. and Moraes, M.H.D. (2010) Seed Treatment: History, Types, Characteristics and Benefits. Informativo ABRATES, 20, 52-71.

[26] Conceição, G.M., Barbieri, A.P.P., Lúcio, A.D., Martin, T.N., Mertz, L.M., Mattioni, N.M. and Lorentz, L.H. (2014) Seedling Performance and Soybean Yield under Different Chemical Treatments in the Seeds. Bioscience Journal, 30, 1711-1720.

[27] Verma, O. and Verma, R.S. (2014) Effect of Seed Coating Material and Storage Containers on Germination and Seedling Vigour of Soybean (Glycine max L.). SAARC Journal of Agriculture, 12, 16-24. 